\title{
SPECIFICITY OF LENS INITIATOR tRNA FOR
}

\author{
N-TERMINAL RECOGNITION
}

\author{
G.J. A.M. STROUS AND H. BLOEMENDAL
}

Dept. of Biochemistry, University of Nïmegen, Nijmegen, The Netherlands

(Received 30 May, 1973)

\begin{abstract}
The optimal magnesium ion concentration for chain initiation in a cell-free system derived from bovine eye lens which synthesizes 4 classes of crystallins appears to be $5 \mathrm{mM}$. In the synthesis of $\alpha$-crystallin polypeptides which contain one internal methionine residue and the second one in $\mathrm{N}$-terminal position, Met-RNA ${ }^{\mathrm{fMet}}$ functions exclusively as initiator. On the other hand at $5 \mathrm{mM} \mathrm{Mg}^{2+}$ Met-tRNA ${ }^{\text {Met }}$ inserts its methionine into the internal position. However, at higher magnesium ion concentrations the initiator tRNA also donates methionine for chain elongation while at the same time the cell-free system loses its capacity to initiate new polypeptides.
\end{abstract}

\section{INTRODUCTION}

Since Marcker and Sanger found that formyl-methionyl-tRNA (F-Met-tRNA ${ }^{\mathrm{fMet}}$ ) was the initiator for the biosynthesis of protein in bacteria [1] a number of reports appeared in the literature describing the function of initiator tRNA in eukaryotes [2-7].

On the other hand it has recently been reported that in mammalian systems initiator Met-tRNA can also donate methionine for internal sequences of polypeptides [8-13]. It appears that the degree to which the initiator tRNA can serve as a donor of internal methionine moiety is strongly affected by (a) the availability of Met-tRNA ${ }^{\text {Met }}$ in the reaction mixture and (b) the ionic conditions under which the reaction is carried out. The utilization of Met-tRNA ${ }^{\mathrm{fMet}}$ in chain elongation would seem to be dependent on the affinity of Met-tRNA ${ }^{\text {fMet }}$ to the elongation factor $T_{1}$ which causes a binding of aminoacyl-tRNA to the A-site of the ribosome. It has been shown that the magnesium ion concentration strongly affects this affinity.

The occurrence of three Met-tRNA species in eye lens tissue has been described previously; one of these acts as initiator in protein synthesis whereas the others promote chain elongation [14].

In the present paper we demonstrate that at low magnesium ion concentration the transfer of methionine from Met-tRNA ${ }^{\text {Met }}$ is dependent upon the incorporation of methionine from MettRNA $^{\mathrm{fMet}}$ into the $\mathrm{N}$-terminal position and that at $\mathbf{M g}^{2+}$ concentrations higher than $5 \mathrm{mM}$ Met-tRNA ${ }^{\text {fMet }}$ loses its specificity as initiator.

\section{MATERIALS AND METHODS}

Lens tRNA was isolated and separated into three chromatographically distinct fractions capable to promote methionine incorporation [14]. Initiator tRNA was charged with $\left({ }^{35} \mathrm{~S}\right)$ methionine 
(spec. act. $40 \mathrm{Ci} \mathrm{mmol}^{-1}$ ) using a crude preparation of aminoacyl-tRNA synthetases from $E$. coli. $\left({ }^{35} \mathrm{~S}\right)$ Met-tRNA ${ }^{\mathrm{fMet}}$ prepared according to this procedure did not contain any $\left({ }^{35} \mathrm{~S}\right) \mathrm{Met}^{-\mathrm{R} R \mathrm{~A}^{\mathrm{Met}}}$ [16].

The procedure for in vitro synthesis of eye lens proteins has been described previously [15]. To prevent re-utilization of $\left({ }^{35} \mathrm{~S}\right)$ methionine hydrolyzed from tRNA ${ }^{\mathrm{fMet}}$ and bound to tRNA ${ }^{\mathrm{Met}}$ a large excess of unlabeled methionine was present in the incubation mixture.

Separation of eye lens crystallins according to molecular weight was carried out following the procedure of Schoenmakers et al. [17]. The procedures for different proteolytic digestions have been described previously $[16,18,19]$. Analysis of the resulting peptides was performed by high voltage paper electrophoresis at $\mathrm{pH} 6.5$ for $2 \mathrm{hr}$ at $50 \mathrm{~V} \mathrm{~cm}^{-1}$. The electropherograms were cut into 1-cm strips which were counted in a liquid scintillation counter using a toluene based scintillator. Unlabeled reference peptides were stained with platinic iodide [20].

\section{RESULTS AND DISCUSSION}

In the cell-free system derived from calf lenses the optimal magnesium ion concentration for amino acid incorporation is $5 \mathrm{mM}$. As shown in Fig. 1 the $\mathrm{Mg}^{2+}$ concentration curve exhibits a shoulder between 7 and $12 \mathrm{mM}$.

From previous experiments it can be concluded that, if $\left({ }^{35} \mathrm{~S}\right) \mathrm{Met}_{\mathrm{H}} \mathrm{RNA}{ }^{\mathrm{fMet}}$ is used in the lens cell-free system the radioactivity is almost completely transferred to the $\mathrm{N}$-terminus of $\alpha$-crystallin polypeptides [16]. Moreover all newly synthesized chains are $\mathrm{N}$-terminally acetylated. To see whether the magnesium ion concentration influences the specificity of the initiator tRNA a lens

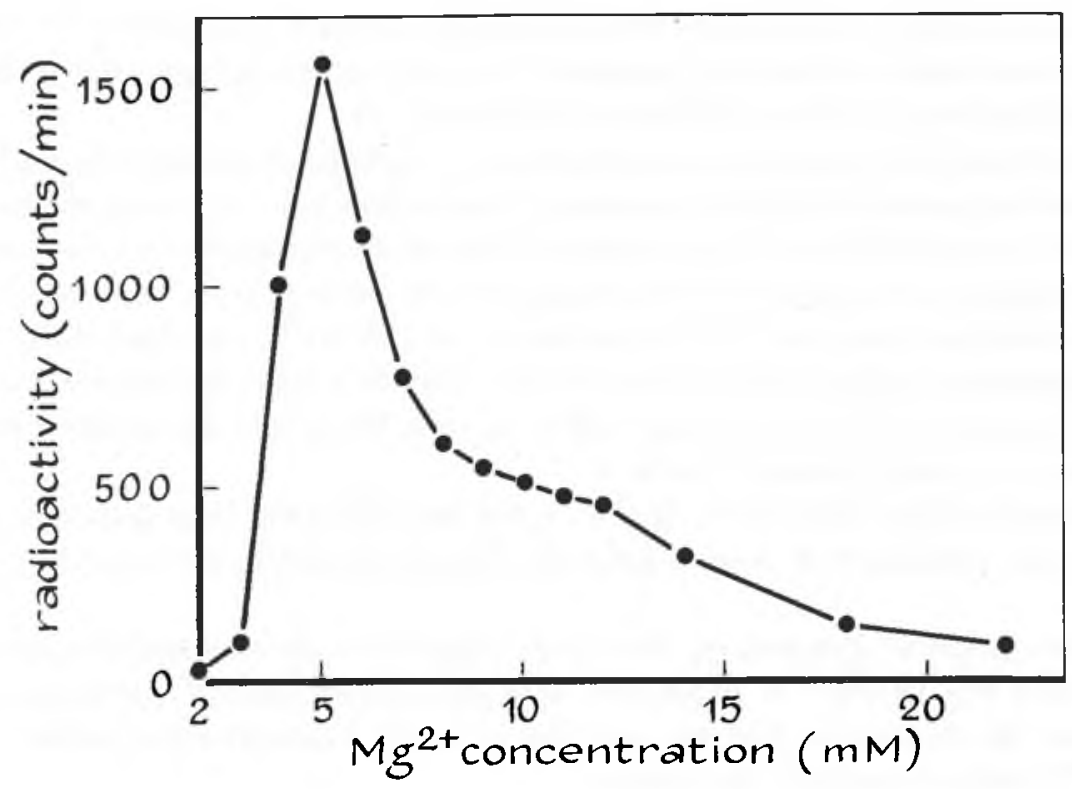

Fig. 1. Effect of magnesium ion concentration on the incorporation of methionine into lens proteins using ( ${ }^{35} \mathrm{~S}$ )Met-tRNA ${ }^{\mathrm{fMet}}$. Incubations were carried out as described in the method section in a total volume of $0.05 \mathrm{ml}$. After incubation $0.02 \mathrm{ml}$ samples were withdrawn and treated with $0.5 \mathrm{ml}$ of $0.1 \mathrm{M} \mathrm{NaOH}$; the protein was precipitated and washed with $5 \%$ trichloroacetic acid and collected on glass fiber filters. The magnesium concentrations mentioned in the figure are composed of the contribution of $\mathrm{Mg}^{2+}$ present in the lysate plus the amount of magnesium added. 


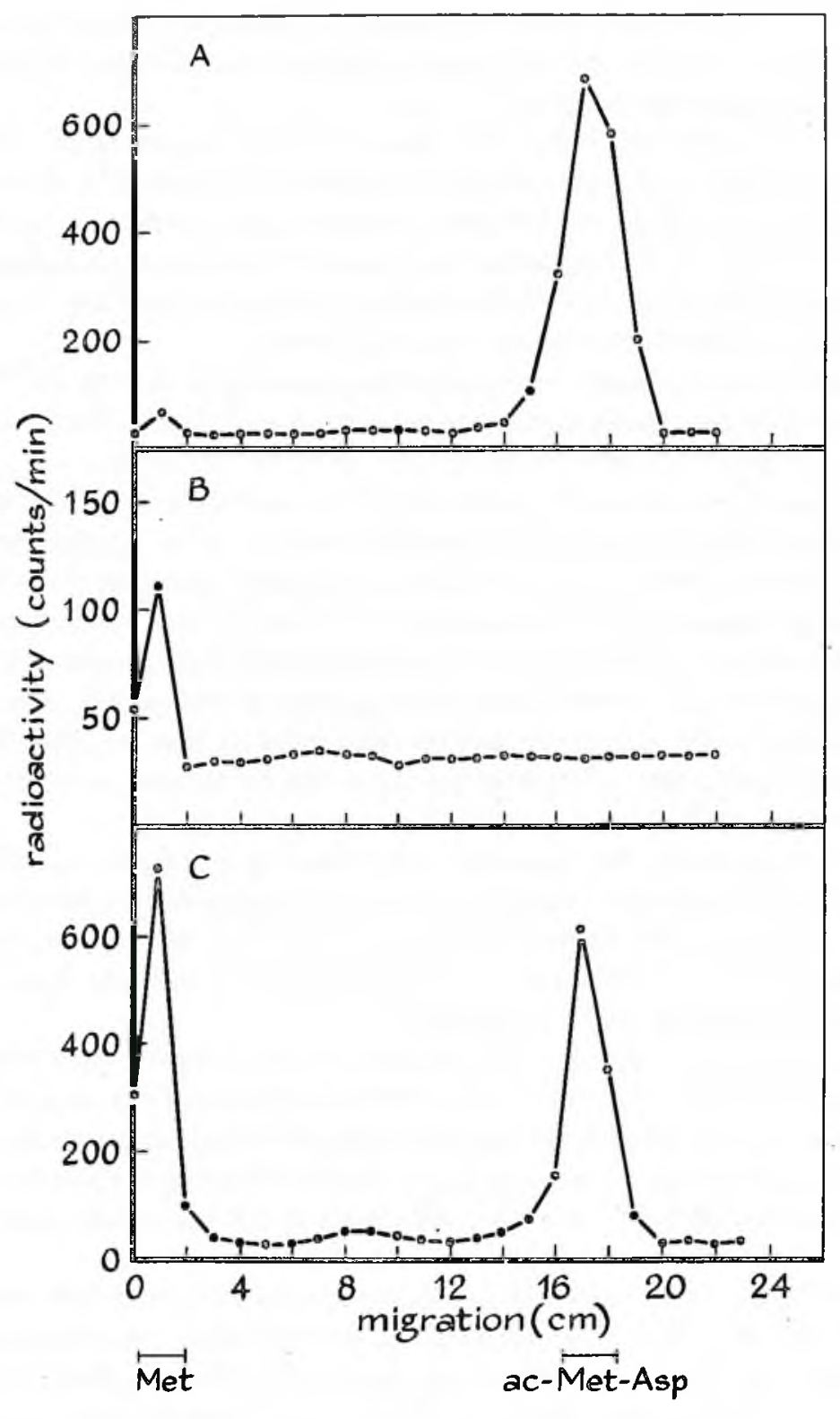

Fig. 2. Identification of $\alpha$-crystallin peptides after digestion with pronase. Incubations $(0.5 \mathrm{ml})$ were carried out as described in the method section, with exception of the $\mathbf{M g}^{2+}$ concentration which was varied. After incubation at $30^{\circ} \mathrm{C}$ for $30 \mathrm{~min}$ the remaining labeled tRNA was destroyed by RNAase treatment and the reaction mixture was passed through a Sephadex G-200 column. The peak containing $\alpha$-crystallin was pooled, the protein solution was dialyzed and lyophilized. The protein was digested with pronase at $37^{\circ} \mathrm{C} \mathrm{for} 6 \mathrm{hr}$ in a total volume of $0.5 \mathrm{ml}$. Then the solution was acidified with acetic acid and lyophilized. Electrophoresis was performed on Whatman 3 MM paper at pH 6.5. Staining with platinic iodide revealed sulfur containing spots in the digested $\alpha$-crystallin preparations with the same electrophoretic behavior as synthetic ac-Met-Asp. (A) Incubation carried out at $5 \mathrm{mM} \mathrm{Mg}^{2+}$. (B) Incubation carried out at $11 \mathrm{mM} \mathrm{Mg} \mathrm{Mg}^{2+}$. (C) Incubation carried out at $5 \mathrm{mM} \mathrm{Mg}^{2+}$ using ( ${ }^{35} \mathrm{~S}$ ) methionine. In (A) and (B) ${ }^{\left({ }^{35} \mathrm{~S}\right)}$ Met-tRNA ${ }^{\text {MMet }}$ was used as radioactive label. 
lysate was incubated using $\left({ }^{35} \mathrm{~S}\right)$ Met-tRNA ${ }^{\mathrm{fMet}}$ as radioactive label at two different $\mathbf{M g}^{\mathbf{2}}$ concentrations ( 5 and $12 \mathrm{mM}$ ). In both cases $\alpha$-crystallin was isolated by gel filtration on Sephadex G-200 and the purified $\alpha$-crystallin was subjected to digestion with pronase. Paper electrophoretic analysis of the resulting peptides is shown in Fig. 2.

After incubation at $5 \mathrm{mM} \mathrm{Mg}^{2+}$ the label was exclusively incorporated in the $\mathrm{N}$-terminal dipeptide Ac-Met-Asp (Fig. 2A), whereas after incubation at $11 \mathrm{mM}$ the radioactivity was recovered exclusively in the position of methionine, which originated from the internal methionine peptide of $\alpha$-crystallin (Fig. 2B). In Fig. 2C the distribution of radioactivity is depicted after pronase digestion of $\alpha$-crystallin labeled with $\left({ }^{35} \mathrm{~S}\right)$ methionine. In this case both the $\mathrm{N}$-terminal and the internal methionine containing peptides were equally labeled.

A second approach has been made to investigate the specificity of Met-tRNA ${ }^{\mathrm{fMet}}$ in dependence on the $\mathrm{Mg}^{2+}$ concentration. Incubations were performed at 5,7 and $12 \mathrm{mM} \mathrm{Mg}^{2+}$. After incubation the reaction mixtures were treated with $0.1 \mathrm{M} \mathrm{KOH}$, the protein was precipitated with $5 \%$ trichloroacetic acid and extensively washed with 5\% trichloroacetic acid and ethanol. Then the protein was subjected to digestion with subtilisin, and the resulting peptides were analyzed by paper electrophoresis at $\mathrm{pH} 6.5$ (Fig. 3). It has been demonstrated earlier that subtilisin digestion yields the $\mathrm{N}$-terminal tetrapeptide of $\alpha$-crystallin [19]. It can be seen that by raising the $\mathbf{M g}^{2+}$ concentration the amount of radioactivity in the tetrapeptide region decreases in favor of the radioactivity derived from the internal methionine peptide at the starting zone. We have also analyzed thermolytic peptides in order to rule out the possibility that at higher $\mathrm{Mg}^{2+}$ concentrations the acetylating mechanism is inhibited leaving a free methionine at the $\mathrm{N}$-terminus which might be split off by pronase as well as subtilisin.

It has been shown previously that digestion with thermolysin of either acetylated or unacetylated polypeptides from $\alpha$-crystallin yields the $\mathrm{N}$-terminal dipeptides Ac-Met-Asp and Met-Asp respectively [16]. Analysis of the thermolytic peptides did not reveal any Met-Asp when the incubation was performed at $12 \mathrm{mM} \mathrm{Mg}^{2+}$; only radioactivity with the same electrophoretic mobility as the internal peptide could be detected.

The present results support the idea that magnesium ion concentrations higher than $5 \mathrm{mM}$ bring about a loss of specificity of the initiator tRNA and destroy the capacity of the protein synthesizing machinery to initiate new polypeptide chains. Most probably only the free $\mathrm{Mg}^{2+}$ concentration in the reaction mixture is important for faithful functioning of the initiation mechanism.

The utilization of Met-tRNA ${ }^{\mathrm{fMet}}$ for chain elongation in cell-free systems can be explained in three ways:

(a) The tRNA ${ }^{\mathrm{fMet}}$ molecules from different eukaryotes or even from different organs of the same species are different in their structures which causes variations in the affinity for the T-factor.

(b) The $T_{1}$ elongation factors from different tissues exhibit different affinity for Met-tRNA ${ }^{\mathrm{fMet}}$.

(c) Ionic conditions influence the complex constant for the formation of a complex between $T_{1}$ and initiator tRNA.

With the exception of the initiator tRNA from yeast and wheat germ, which tRNA species seem to differ in structural respect from mammalian tRNAs [10, 21], at the moment there are no data available which support the idea that structural differences exist between initiator tRNAs from different eukaryotic sources.

More is known about the role of elongation factor $T_{1}$. Several workers have studied the complex formation at the A-site of mammalian ribosomes between initiator tRNA, GTP and the transfer factor in the presence of poly AUG or endogenous messenger RNA [10-12, 21]. In fact the crucial point seems to be the degree of recognition of Met-tRNA ${ }^{\text {(Met }}$ by the polymerizing enzymes. This affinity can be influenced by the availability of Met-tRNA ${ }^{\mathrm{Met}}$ and by ionic conditions. 
From our experiments it is apparent that, even when a crude lens lysate is incubated, the specificity of the initiator tRNA is strongly influenced by the magnesium concentration. In Fig. 1 the shoulder in the curve for methionine incorporation via Met-tRNA ${ }^{\text {fMet }}$ (between 7 and $12 \mathrm{mM}$ $\mathrm{Mg}^{2+}$ ) has to be considered as a range of $\mathrm{Mg}^{2+}$-concentrations where tRNA ${ }^{\mathrm{fMet}}$ provides methionine for both initiation and elongation. The donation of methionine via Met-tRNA ${ }^{\text {fMet }}$ to internal positions in the polypeptide chain may be considered to be non-physiological and a consequence of the complex formation between transfer factors and initiator tRNA.

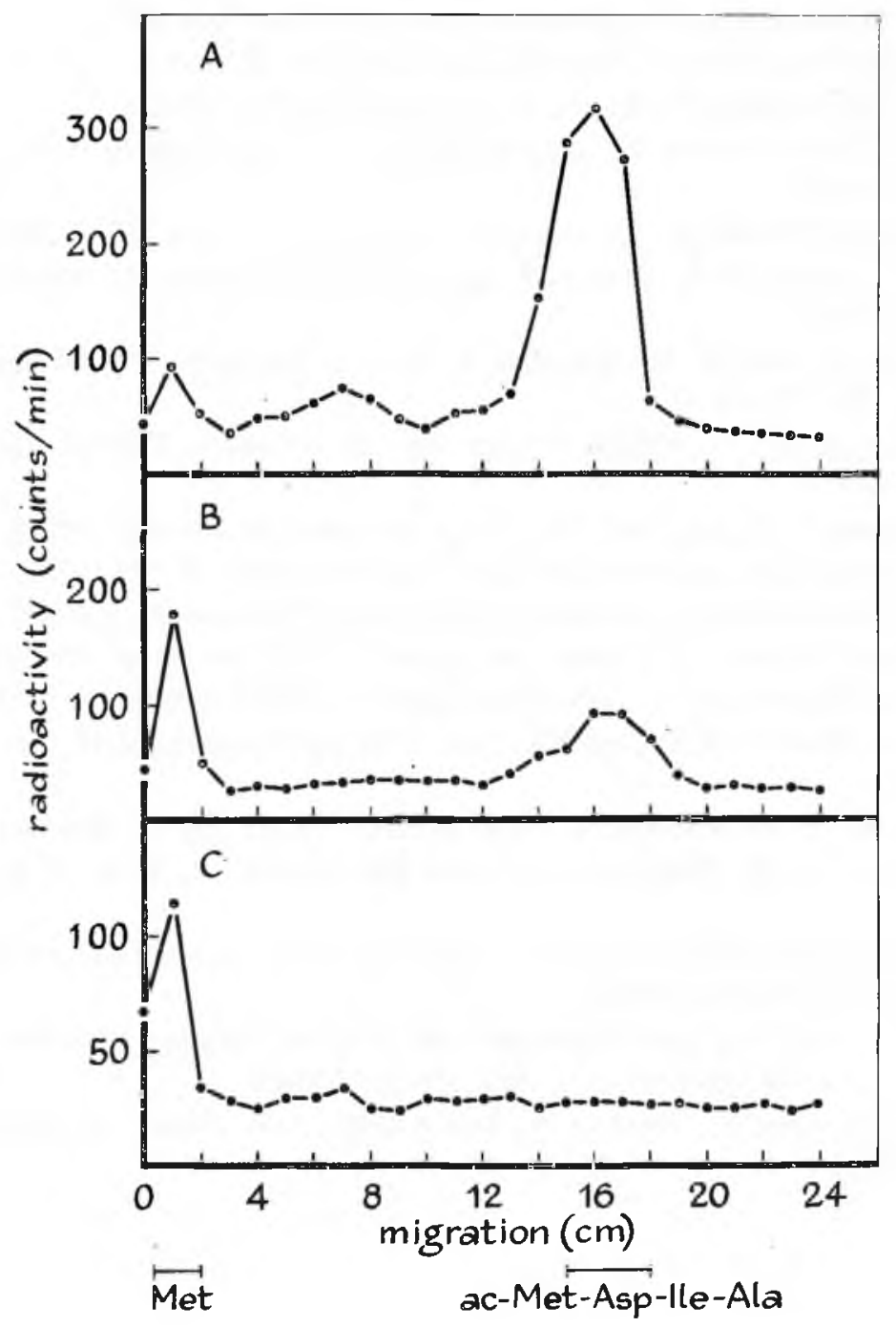

Fig. 3. Specificity of initiator tRNA in the synthesis of eye lens proteins. Incubations ( $0.2 \mathrm{ml})$ were carried out as described in Section II at three different $\mathrm{Mg}^{2+}$ concentrations. ${ }^{35} \mathrm{~S}$ ) Met-tRNA ${ }^{\mathrm{PM}}$ et was used as radioactive precursor. After incubation at $30^{\circ} \mathrm{C}$ for $30 \mathrm{~min} 0.02 \mathrm{ml}$ of $1 \mathrm{M} \mathrm{NaOH}$ was added and the incubation was continued for 15 min. $2 \mathrm{ml}$ of $5 \%$ trichloroacetic acid was added; the precipitate was spun, dissolved in $2 \mathrm{ml}$ of $0.1 \mathrm{M} \mathrm{NaOH}$ and precipitated again with $5 \%$ trichloroacetic acid. This treatment was repeated twice. Then the precipitate was washed with ethanol and dried. Digestion was performed with subtilisin and the resulting peptides were analyzed by paper electrophoresis at pH 6.5. Chemically synthesized Ac-Met-Asp-Ile-Ala was used as reference. The magnesium ion concentration used was (A) $5 \mathrm{mM}$, (B) $7 \mathrm{mM}$ and (C) $12 \mathrm{mM}$, respectively. 


\section{ACKNOWLEDGEMENTS}

The present investigations have partly been carried out under auspices of the Netherlands Foundation for Chemical Research (S.O.N.) and with financial aid of the Netherlands Organization for the Advancement of Pure Research (Z.W.O.).

\section{REFERENCES}

1. Marcker, K. and Sanger, G., J. Mol. Biol. 8, 835-840 (1964).

2. Smith, A. E. and Marcker, K. A., Nature (Lond.) 226, 607-610 (1970).

3. Brown, J. C. and Smith, A. E., Nature (Lond.) 226, 610-612 (1970).

4. Jackson, R. J. and Hunter, A. R., Nature (Lond.) 227, 672 (1970).

5. Housman, D., Jacobs-Lorena, M., Ray Bandary, U. L., and Lodish, H. F., Nature (Lond.) 227, 913-918 (1970).

6. Wilson, D. B. and Dintzis, H. M., Proc. Nat. Acad. Sci. U.S. 66, 1282-1289 (1970).

7. Bhaduri, S., Chatterjee, N. K., Bose, K. K., and Gupta, N. K., Biochem. Biophys. Res. Commun. 40, 402-407 (1970).

8. Chatterjee, N. K., Bose, K. K., Woodley, C. L., and Gupta, N. K., Biochem. Biophys. Res. Commun. 43, 771-779 (1971).

9. Drews, J., Högenauer, G., Unger, F., and Weil, R., Biochem. Biophys. Res. Commun. 43, 905-912 (1971).

10. Drews, J., Grasmuk, H., and Weil, R., Eur. J. Biochem. 26, 416-425 (1972).

11. Drews, J., Grasmuk, H., and Weil, R., Eur. J. Biochem. 29, 119-127 (1972).

12. Ghosh, H. P. and Ghosh, K., Biochem. Biophys. Res. Commun. 49, 550-557 (1972).

13. Öberg, B. F. and Shatkin, A. J., Proc. Nat. Acad. Sci. U.S. 69, 3589-3593 (1972).

14. Strous, G., van Westreenen, H., and Bloemendal, H., FEBS Letters 19, 33-37 (1971).

15. Strous, G. J. A., Berns, A. J. M., van Westreenen, H., and Bloemendal, H., Eur. J. Biochem. 30, 48-52 (1972).

16. Strous, G. J. A., van Westreenen, H., and Bloemendal, H., Eur. J. Biochem (1973) in press.

17. Schoenmakers, J. G. G., Hoenders, H. J., and Bloemendal, H., Exptl. Eye Res. 7, 172-181 (1968).

18. Hoenders, H. J., Schoenmakers, J. G. G., Gerding, J. J. T., Tesser, G. I., and Bloemendal, H., Exptl. Eye Res. 7, 291-300 (1968).

19. Hoenders, H. J., van Tol, J., and Bloemendal, H., Biochim. Biophys. Acta 160, 283-285 (1968).

20. Easley, C. W., Biochim. Biophys. Acta 107, 386-388 (1965).

21. Richter, D., Lipmann, F., Tarrago, A., and Allende, J. E., Proc. Nat. Acad. Sci. U.S. 68, 1805-1809 (1971). 